\title{
A Select Survey of Criminal Justice Administration and Criminology Resources for Research, Reference, and Collection Development
}

Richard A. Stoddart, Brett Spencer, and Adrienne R. McPhaul, Guest Columnists

Correspondence concerning this column should be addressed to Neal Wyatt, The Alert Collector, c/o RUSA, 50 E. Huron, Chicago, IL 60611; alertcollector@comcast.net.Wyatt is a collection development and readers' advisory librarian from Virginia. She wrote The Readers' Advisory Guide to Nonfiction (ALA Editions, 2007) and is an editor of Library Journal's "Reader's Shelf" column and compiles LJ's weekly "Wyatt's World Lists."

\section{Richard A. Stoddart is Reference} Librarian-Liaison to Criminal Justice, Albertsons Library, Boise (Idaho) State University. Brett Spencer is Reference Librarian-Liaison to Criminal Justice, Gorgas Library, University of Alabama, Tuscaloosa. Adrienne R. McPhaul is Information Services LibrarianLiaison to Criminal Justice, Cook Library, The University of Southern Mississippi, Hattiesburg.
This column illustrates the best of outcomes when colleagues assist one another in developing subject expertise and in building collections. As all of us in the collection development world know, crafting well-developed collections in subject-specific areas is a constant challenge. Taking up this challenge in a subject specialty you do not know well is, to put it lightly, a daunting prospect. When Rick Stoddart found himself in that position, he turned to Brett Spencer and Adrienne McPhaul for assistance. Spencer and McPhaul have almost ten years of criminal justice collection liaison experience between them, and both agreed to help Stoddart get up to speed on critical materials for his collection. The result of their collaboration was a list of core resources as well as several tables of comparisons between resources that can be used not only to build collections but also to quickly see the scope and capabilities of each relevant database and resource. As we are called upon to work more frequently in areas we do not know well, it can only be hoped that we will follow the model of Stoddart, Spencer, and McPhaul and work collaboratively to build both our collections and our expertise. As editor of "The Alert Collector," I hope that this space can serve not only as a place to publish the fruits of those collaborations but also to aid librarians in sharing their specialty subject knowledge with the widest range of colleagues._Editor

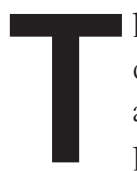

he field of criminal justice administration/criminology (CJAC) plays a vital role in American society, and many colleges include CJAC departments. CJAC professors perform research that informs the nation's law enforcement policies, and their contributions are gaining increasing importance with the rise of terrorism, identity theft, and new cybercrimes. CJAC is also attracting more and more 


\section{THE ALERT COLLECTOR}

students because of the popularity of crime-fighting themes in American media (perhaps best epitomized by the various CSI television series) as well as the expanding job opportunities in the field. Accordingly, libraries should strive to provide relevant resources that meet the growing research and curricular needs of CJAC departments. This article presents a select list of current resources available to libraries in this subject area.

In defining the field, criminal justice concerns itself with the mechanisms and social forces that counter crime, while criminology typically relates to the theories of why people commit crime. ${ }^{1}$ Criminal Justice and Criminology both fall under the general umbrella of the social sciences and most often specifically reside as a subdiscipline of sociology. Librarians serving CJAC patrons can thus consult general social sciences resources (as shown by the inclusion of the Sociological Abstracts database in this article) as well as CJAC-specific resources.

Fortunately, publishers are producing many excellent resources. Gale-InfoTrac (Cengage Learning), Cambridge (ProQuest), Ebscohost, and other publishers have created databases with full-text or abstract coverage strong enough to support research in most CJAC subject areas. In addition, the federal government collects a huge amount of CJAC data that it now makes available through free Web portals. Further, in recent years, many leading authors have published outstanding reference books that summarize the theory and practice of CJAC from sociological, legal, historical, and other perspectives. Librarians must be knowledgeable about these resources in order to tailor their collection and reference service to the interests of their campus clientele.

This overview of databases, websites, encyclopedias, journals, and book series is not meant to be a comprehensive list but only to provide a select survey for possible research and collection development purposes. The authors focused on generalized resources and took into account the size, currency, and scholarly value of the resources' contents and the usefulness of these resources in their own libraries. In-depth CJAC collection tools are found in Criminal Justice Research Sources. ${ }^{2}$ Criminal Justice Research in Libraries: Strategies and Resources also offers in-depth research guides in this subject area. ${ }^{3}$ In addition, Dodge provides a detailed overview of CJAC-related websites that also can be of research value. ${ }^{4}$

The tables accompanying this article provide a quick and easy comparison of some of the CJAC resources covered. Specifically, the tables deal with related subscription databases and encyclopedias and seek to outline the basic coverage and comparison for each resource. For example, table 1 compares the available subscription CJAC databases by number of publications indexed, number of full-text titles available, number of records in each database, and earliest coverage. All comparisons were completed in February and March 2008.

\section{SUBSCRIPTION DATABASES}

Online databases offer many advantages to users including providing $24 / 7$ remote access, direct access to full-text articles, and ease of searching. With the parent companies of many databases recently merging, it has been a turbulent time in the online vendor field. These mergers may have affected CJAC databases, especially with the recent marriage of ProQuest and Cambridge Scientific Abstracts (CSA). These two vendors count three CJAC databases among their products: Criminal Justice Abstracts (CSA), Criminology: A Sage Full-Text Collection (CSA), and Criminal Justice Periodicals (ProQuest). It remains to be seen what actual changes may occur to interface designs and overall content, but it is worth taking note that changes may occur in the future. At the time of this comparison, these databases remained true to each company interface and they did not appear to merge content. All databases have similar quick (or basic) and advanced search screens, which most librarians and researchers are familiar with.

To help with the comparison of the subscription databases, a chart is provided that outlines some basic differences between the products (see table 1). An additional table provides basic search results in each database for common search terms (see table 2). This second table was constructed by initiating a quick search in each database for the general term "criminology" and also the subject-specific terms "recidivism" and "homicide." No limiters or other specific search features were selected. This was felt to most likely reflect a first search undertaken by patrons. Results for each comparison were rounded up to the nearest hundredth for ease of use and to adjust slightly for the addition of records that may occur in the interim. The comparison found in table 2 was not meant to be all-inclusive but rather to serve as a tool to better understand the scope of each database.

\section{Criminal Justice Abstracts (CSA)}

The database Criminal Justice Abstracts is basically equivalent to the print index of the same name published by Sage. Content is drawn from journals, books, and dissertations, among other sources. The database provides a Search Tools feature under one of the function tabs. Here a researcher can do command searching; access a very useful criminology thesaurus; use the database index to search by author, descriptor, journal name, and publication type; view search history; create alerts for search terms; and so on. This database's strength is as an aid for finding material in the various CJAC journals.

For more information on Criminal Justice Abstracts, see www-md2.csa.com/factsheets/cja-set-c.php.

\section{Sociological Abstracts (CSA)}

Sociological Abstracts contains many CJAC-related journals and articles, but it provides a broader search across the sociological discipline. One feature to note is that Sociological Abstracts provides a means for locating scholars by research field (including criminal justice). For example, initiating a quick search for the term "criminology" not only returns just more than thirteen thousand records but also includes more 
Table 1. Information Gathered from Database Product Literature

\begin{tabular}{|c|c|c|c|c|}
\hline Database & $\begin{array}{l}\text { No. of } \\
\text { Publications } \\
\text { Indexed }\end{array}$ & $\begin{array}{l}\text { No. of Titles } \\
\text { with Full-text }\end{array}$ & No. of Records & $\begin{array}{l}\text { Earliest } \\
\text { Coverage } \\
\text { Available }\end{array}$ \\
\hline $\begin{array}{l}\text { Criminal } \\
\text { Justice } \\
\text { Abstracts (CSA) }\end{array}$ & Not Given & Few & $\begin{array}{l}95,253 \\
\text { (as of } 2 / 08 \text { ) }\end{array}$ & 1968 \\
\hline $\begin{array}{l}\text { Criminology } \\
\text { (Sage full-text) }\end{array}$ & 24 & All & Not given & 1976 \\
\hline $\begin{array}{l}\text { Criminal } \\
\text { Justice } \\
\text { Periodical } \\
\text { Index } \\
\text { (ProQuest) }\end{array}$ & $240+$ & Some & Not given & 1981 \\
\hline $\begin{array}{l}\text { Criminal } \\
\text { Justice } \\
\text { (InfoTrac) }\end{array}$ & $150+$ & $\begin{array}{l}\text { Significant } \\
\text { majority }\end{array}$ & Not given & Approx. 1980 \\
\hline $\begin{array}{l}\text { Criminal } \\
\text { Justice eCollec- } \\
\text { tion (Thomson } \\
\text { Gale) }\end{array}$ & $165+$ & $\begin{array}{l}\text { Significant } \\
\text { majority }\end{array}$ & Not given & Approx. 1980 \\
\hline $\begin{array}{l}\text { Sociological } \\
\text { Abstracts (CSA) }\end{array}$ & $1800^{*}$ & Few & $\begin{array}{l}826,575 \\
\text { (as of } 2 / 08 \text { ) }\end{array}$ & 1952 \\
\hline $\begin{array}{l}\text { SocIndex with } \\
\text { Full-Text } \\
\text { (EBSCO) }\end{array}$ & $2900+*$ & Some & 1.9 million & 1895 \\
\hline
\end{tabular}

Table 2. Sample Search Comparison: Number of Records for Search Terms

\begin{tabular}{|c|c|c|c|}
\hline Database & Criminology & Recidivism & Homicide \\
\hline Criminal Justice Abstracts (CSA) & 10,000 & 3,800 & 3,400 \\
\hline Sociological Abstracts (CSA) & 13,000 & 1,500 & 3,000 \\
\hline Criminology (Sage full-text) & 8,500 & 3,000 & 2,600 \\
\hline Criminal Justice Periodical Index (ProQuest) & 10,000 & 2,000 & 2,000 \\
\hline Criminal Justice (InfoTrac) & 1,000 & 600 & 1,500 \\
\hline SocIndex with Full-Text (EBSCO) & 37,000 & 7,100 & 7,700 \\
\hline
\end{tabular}

searches for the more specific term "recidivism," the database returns only fifteen hundred results compared to Criminal Justice Abstracts' (thirty-eight hundred). These two disparate search results speak to the strength of using a subject-specific database indexed specifically for that discipline. However, on the basis of the number record results returned for "criminology," it is not worth forgetting the strengths of a good social sciences resource either. For more information see Sociological Abstracts: www-md3 .csa.com/factsheets/socioabs-set -c.php.

Criminology: A Sage Full-Text Collection (CSA/ProQuest)

As opposed to covering the breadth of study like Criminal Justice Abstracts/Sociological Abstracts, this CSA database offers full-text access to select Sage journal titles in criminology. The collection includes full text for twenty-four journals. While not the most comprehensive database (that is not its purpose) it does provide full text for all its titles, which is a major boon to any researcher. Depending on specific library needs, this database would make a good full-text complement to the finding aid that is Criminal Justice Abstracts.

For more information, see www-md2.csa.com/factsheets/ sagecrim-set-c.php.

Criminal Justice Periodicals Index (ProQuest/CSA)

Originally solely a ProQuest product, this has now been acquired in the CSA/ProQuest merger. At the time of this survey, the database indexed 240 titles and provided full text in some form for approximately eighty. Overall, this

than thirty-four hundred scholars and researchers associated with that term. Interestingly, even though Sociological Abstracts returned more records related to the term "criminology" than Criminal Justice Abstracts (ten thousand), if one is a well-balanced database providing adequate full text and breadth of coverage for CJAC subjects and related areas.

For more information, see http://il.proquest.com/ products_pq/descriptions/pq_criminal_justice.shtml. 


\section{THE ALERT COLLECTOR}

InfoTrac Criminal Justice/Thomson Gale eCollection Criminal Justice (Thomson-Gale/Cengage Learning)

InfoTrac Criminal Justice and the Criminal Justice eCollection are similar products offered by Thomson-Gale. Both databases contain the same journal titles available in the InfoTrac Criminal Justice database. The only difference between the products is that the eCollection also contains sixteen criminal justice related e-books drawn from across Thomson-Gale, Sage, and McMillan reference products. The reference works in the eCollection include such titles as the Encyclopedia of Law Enforcement, Encyclopedia of Crime and Justice, Encyclopedia of White-Collar and Corporate Crime, and the Encyclopedia of Terrorism. There are more 150 journals indexed in these collections with a significant number available in full text, including coverage of the Uniform Crime Reports from 1999. Overall, there is sufficient coverage of CJAC journals in both databases with the added strength of the eCollection being able to search the full-text reference books.

For more information, see www.gale.com/pdf/facts/ eCollections.pdf.

\section{SocINDEX with Full Text (EBSCO)}

EBSCO supplies excellent CJAC coverage in SocIndex with Full Text. This database indexes a significant amount of social science journals providing more than double the number of records available in most CJAC subject areas in comparison with the CSA/ProQuest products (Criminal Justice Abstracts and Sociological Abstracts). In addition, SocIndex provides over ten thousand author profiles in the social sciences. This entire database is a powerful and comprehensive resource for research in the social sciences, including the CJAC subject areas.

For more information, see www.epnet.com/thisTopic .php?marketID=1\&topicID=138.

\section{WEBSITES}

CJAC primary documents as well as indexes, statistics, and finding aids abound in the online environment. Many valuable traditional reference resources, such as The Statistical Abstract of the United States (www.census.gov/compendia/statab) and CJAC specific resources like the Uniform Crime Reports (www.fbi.gov/ucr/ucr.htm), are now available electronically. Since CJAC is a complex field that crosses many disciplines, the number of subtopics could make a list of websites quite lengthy. The three resources listed here represent sites that are notable for their research value, currency, and overall relevance to the subject.

National Criminal Justice Reference Center (NCJRS), www .ncjrs.gov

No list of CJAC Web resources would be complete without mentioning the NCJRS. This federally funded clearinghouse of information has been an essential tool for researching information on justice and substance abuse for over thirty years. After undergoing three major redesigns, the site is not only informative but also user friendly. The NCJRS site offers users the opportunity to register for an account to receive newsletters, e-mails about new publications and resources, announcements, and invitations to relevant discussion lists. This is an indispensable resource for anyone looking for reliable CJAC information.

\section{U.S. Department of Justice (DOJ), www.usdoj.gov}

Much of the information included in this website is indexed in the National Criminal Justice Reference Center, but since this government agency is the genesis of much of the primary federal information included in criminal justice resources, it is often worthwhile to go directly to the source. There are many agencies within the DOJ, from the Anti-Trust Division to the U.S. Trustee Program. Other select agencies under the DOJ include the Office of Violence Against Women, the Federal Bureau of Investigation, the National Institute of Corrections, the National Drug Intelligence Center, and the Bureau of Justice Statistics, not to mention most of federal criminal justice-related sources of information mentioned in this survey. As a direct source of information with access to many full-text reports, statistics, and content, this website is a critical resource.

United Nations Interregional Crime and Justice Research Institute (UNICRI), www.unicri.it

For those CJAC researchers who take an international scope in their topics, this website is useful for finding materials not typically catalogued in U.S. libraries. The UNICRI was founded in 1967 to help "countries world wide in crime prevention and criminal justice." The website is divided into three areas: The Institute, which provides information about the agency itself; Activities, which lists current programs and issues the UNICRI is interested in; and DocumentationInformation, which provides access to related UNICRI publications, websites, and their online library catalogue. Included with the catalogue is a criminological thesaurus that not only provides brief definitions but suggests broader and narrower terms for possible use in a search query.

\section{GENERAL ENCYCLOPEDIAS}

Wright, Richard and J. Mitchell Miller, eds. Encyclopedia of Criminology. New York: Routledge, 2005 (ISBN: 1-57958387-3).

This title is the most recent general encyclopedia on criminology. It has an interdisciplinary and international scope that takes a somewhat more theoretical approach than the other general works. The 525 entries are organized alphabetically and authored by many of the world's leading scholars in criminal justice, sociology, political science, law, and social work. The overall theoretical approach of this work makes it especially useful for students and researchers concerned with explanations about why people engage in deviant behaviors. 
Dressler, Joshua, ed. Encyclopedia of Crime and Justice. 2nd ed. New York: Macmillan, 2002 (ISBN: 0-02-865319-X).

This encyclopedia provides a more legal-oriented perspective than the other general works. Law school professors and judges authored most of the 250 essays, which provide intensive coverage of most topics rather than short sketches. Many of the entries have bibliographies of relevant court cases. Other useful features include a guide to legal citations and a legal index separate from the main index. These tools will thus help students looking for court cases or congressional acts to use as evidence in their papers. Students on pre-law tracks will find this resource especially useful.

Levinson, David, ed. Encyclopedia of Crime and Punishment. Thousand Oaks, Calif.: Sage, 2002 (ISBN: 0-7619-2258-X).

This practitioner-oriented, undergraduate-friendly general encyclopedia is published by Sage, one of the most prolific and reliable disseminators of CJAC information. Sample entries include diverse topics such as: television, child witness, prison industry, religion in prison, wrongful convictions, and environmental crime. The set features quick reference tables with carjacking security tips, principles of community policing, crime statistics charts, and other factoids. Informational tables offer primary documents such as the American Correctional Association's Code of Ethics. Other special features include a reader's guide, chronology, career guide, a guide to CJAC research on the Web, bibliography, and list of professional associations. Researchers at all levels will utilize this set, especially students desiring readable, down-to-earth, yet scholarly essays on the key issues they are likely to face as professionals.

Bryant, Clifton D., ed. Encyclopedia of Criminology and Deviant Behavior. Philadelphia: Brunner-Routledge, 2001 (ISBN:1-56032-772-3).

Bryant gathered the essays for this comprehensive compendium of scholarship from over six hundred experts in criminology and sociology. The set consists of four thematic volumes (Historical, Conceptual, and Theoretical Issues; Crime and Juvenile Delinquency; Sexual Deviance; Self-Destructive Behavior and Disvalued Identity). The thematic organization is of great value to students who have been assigned to write about a theory or crime but need help deciding on a particular topic. In all of the volumes, each essay includes a substantial list of references that are always of great value. Equally useful for novices and advanced researchers, this reference set has been a great starting point for research for many students, and it has influenced many scholars in the field, as a citation search in Google Scholar can demonstrate.

Sifakis, Carl. Encyclopedia of American Crime. 2nd ed. New York: Facts on File, 2001. (ISBN: 0-8160-4040-0).

This encyclopedia, part of the Facts on File Crime Library, provides an overview of crime in American society from a historical perspective. The author, a freelance crime writer, has filled this work with fascinating stories of gangsters, killers, crime fighters, heists, policies, prisons, and other topics. He shows how crime shaped the general history of the United States. Overall, this book is well-written and fun to browse. In terms of its capability to support research, most of the entries do not have associated bibliographies. However, one particular strength of this set compared with other works is its coverage of the history of crime (most criminal justice programs have at least one course on the history of crime). The reader will find essays on such topics as colonial-era crimes, Bluebeard the Pirate, the New York City draft riots of 1863 , the Gopher gang, and notorious outlaws like Jesse James.

Phelps, Shirelle, ed. World of Criminal Justice. Detroit: Gale, 2002 (ISBN: 0-7876-4959-7).

World of Criminal Justice is a great ready reference tool for CJAC in general. The work, aimed at undergraduate students, high school students, and the general public, offers easy-toread thumbnail sketches that can quickly answer questions arising during research. Students preparing for tests can also use this work to supplement their course texts and notes: Sometimes they may need a brief extra clarification of a term that they encounter in their studying. Features of this book include pictures, an index, and a chronology. The boldface cross-referenced words within each essay will appeal to those accustomed to navigating the hyperlinked world of the Internet. The referenced works in each entry are included in a large bibliography at the back of the book rather than at the end of each essay, thus requiring the researcher to flip between the pages. However, the ease of use and conciseness of the essays means that this reference set will be of great use for quick access to key CJAC topics.

There is substantial overlap in coverage of common topics in these general CJAC reference works. For example, one will find entries on common topics like robbery or boot camps in almost any of these encyclopedias. However, each of the books has some important differences in their approach to the subject, and there are some specific topics that receive coverage in only one of the encyclopedias. By being aware of the differing perspectives of the encyclopedias, CJAC librarians can make the best possible choices in their collection strategies and supply the most relevant information for a specific reference question. Table 3 provides an overview of the differences between these general reference works.

CJAC librarians can further strengthen the usefulness of their reference collections by adding specialized works that address various CJAC subfields, frequently researched crimes and policies, and incidental research needs. Specialized resources exist for several of the major subfields within CJAC: policing, corrections, forensics, law, juvenile justice, and counter terrorism.

\section{SELECT JOURNALS}

There are at least 326 CJAC journals to choose from when building a collection. ${ }^{5} \mathrm{~A}$ tool to measure the strength of a journal relative to its subject area is the number of research 


\section{THE ALERT COLLECTOR}

citations derived from the articles within a journal's pages. A core collection of heavily cited journals provides a strong foundation for any CJAC collection. The select list below is derived from the citation research of Cohn and Farrington, who noted the most cited CJAC researchers and the journals they appear in for the years 1990-2000. ${ }^{6}$ It is also worth remembering that CJAC articles may appear in other social science and sociology journals.

Journal of Interpersonal Violence. Beverly Hills, Calif.: Sage, 1986-. Monthly. (ISSN: 0886-2605).

Criminology. Beverly Hills, Calif.: Wiley-Blackwell, 1963-. Quarterly. (ISSN: 0011-1384).

Journal of Criminal Justice. New York: Pergamon, 1973-. Bimonthly. (ISSN: 0047-2352).

Justice Quarterly. Philadelphia: Routledge, 1984-. Quarterly. (ISSN: 0741-8825).
Criminal Justice and Behavior. Beverly Hills, Calif.: Sage, 1973-. Bimonthly. (ISSN:0093-8548).

International Journal of Offender Therapy and Comparative Criminology. Beverly Hills: Sage, 1957-. Bimonthly. (ISSN: 0306-624X).

Violence and Victims. New York: Springer, 1986-. Bimonthly. (ISSN: 0886-6708).

British Journal of Criminology, The. London: Oxford Univ. Pr., 1950-. Bimonthly. (ISSN: 0007-0955).

\section{MONOGRAPHS SERIES}

Criminal justice and criminology encompasses a wide range of subjects, so it is impossible in this limited space to highlight the many relevant texts needed in a collection. Another approach to monographic collection development in this discipline is to highlight CJAC book series offered by vari-

Table 3. An Overview of the General Encyclopedias of Criminal Justice

\begin{tabular}{|c|c|c|c|c|c|c|}
\hline Reference Title & Description & No. of Entries* & $\begin{array}{l}\text { Typical Length } \\
\text { of Entries } \\
\text { (in words)+ }\end{array}$ & $\begin{array}{l}\text { Year of } \\
\text { Publication }\end{array}$ & Publisher & $\begin{array}{l}\text { Notable } \\
\text { Features }\end{array}$ \\
\hline $\begin{array}{l}\text { Encyclopedia of } \\
\text { Criminology }\end{array}$ & $\begin{array}{l}\text { More theo- } \\
\text { retical, multi- } \\
\text { disciplinary, } \\
\text { international }\end{array}$ & 525 & $2,600-2,700$ & 2005 & Routledge & $\begin{array}{l}\text { Alphabetical and } \\
\text { thematic list of } \\
\text { entries }\end{array}$ \\
\hline $\begin{array}{l}\text { Encyclopedia of } \\
\text { Crime and Justice }\end{array}$ & $\begin{array}{l}\text { Legal } \\
\text { perspective }\end{array}$ & 250 & $800-12,000$ & 2002 & Macmillian & $\begin{array}{l}\text { Legal index, } \\
\text { guide to legal } \\
\text { citations }\end{array}$ \\
\hline $\begin{array}{l}\text { Encyclopedia } \\
\text { of Crime and } \\
\text { Punishment }\end{array}$ & $\begin{array}{l}\text { Practitioner } \\
\text { issues, student- } \\
\text { friendly }\end{array}$ & 430 & $2,200-2,300$ & 2002 & Sage & $\begin{array}{l}\text { Quick reference } \\
\text { tables and pri- } \\
\text { mary documents }\end{array}$ \\
\hline $\begin{array}{l}\text { Encyclopedia of } \\
\text { Criminology and } \\
\text { Deviant } \\
\text { Behavior }\end{array}$ & Sociological & $550+$ & $2,000-3,500$ & 2001 & $\begin{array}{l}\text { Brunner- } \\
\text { Routledge }\end{array}$ & $\begin{array}{l}\text { Organized by } \\
\text { thematic } \\
\text { volumes }\end{array}$ \\
\hline $\begin{array}{l}\text { Encyclopedia of } \\
\text { American Crime }\end{array}$ & $\begin{array}{l}\text { Historical topics } \\
\text { not covered in } \\
\text { other general } \\
\text { works }\end{array}$ & $2,000+$ & Less than 2,000 & 2001 & Facts on File & $\begin{array}{l}\text { Introduction } \\
\text { with overview of } \\
\text { American crime; } \\
\text { photos with } \\
\text { some entries }\end{array}$ \\
\hline $\begin{array}{l}\text { World of } \\
\text { Criminal Justice }\end{array}$ & $\begin{array}{l}\text { Quick reference } \\
\text { tool }\end{array}$ & $1,000+$ & Less than 1,000 & 2002 & Gale & $\begin{array}{l}\text { Boldface terms } \\
\text { in entries are } \\
\text { cross-referenced }\end{array}$ \\
\hline
\end{tabular}

*Estimates on number of essays usually came from the introductions to the reference books. In some cases, the number is based on the current authors' estimates.

+Estimates on average lengths of essays are based on figures provided by the publisher in the introduction whenever possible. When not provided, the authors tallied the averages by performing word counts of sample entries on publisher websites or by manually counting words in random essays in the reference books themselves. 
ous publishers. Knowledge of these series can provide a continuous source of relevant materials for your collections and provide a one-stop source for further collection development efforts in these areas. All series below are active unless otherwise noted and the ISBN will vary by individual book title.

Cambridge Studies in Criminology. Cambridge: Cambridge Univ. Pr., 1996-.

An important series of research monographs that includes over sixty titles dealing with a wide range of topics in CJACs. This is a series that supports serious academic research. www.cambridge.org/uk/browse/browse_highlights .asp? subjectid $=1012359$.

Oxford Monographs in Criminal Law and Justice. Oxford: Oxford Univ. Pr., 1992-.

This ongoing series of more than thirty titles concentrates on both the theoretical and practical aspects of criminal law and procedure. www.oup.co.uk/law/series/monograph-crim.

Criminal Justice: Recent Scholarship. New York: LFB, 2001-.

With over seventy-five titles spread across the subjects of criminal justice, criminology, law and victimology, this book series offers a great overview of topics of interest to the CJAC scholar and student. www.lfbscholarly.com/criminal_justice/ series_cj.htm.

History of Crime and Criminal Justice. The Ohio State Univ. Pr., 1997-.

Active since 1997, this series with twenty titles provides a breadth of coverage dealing with the history of crime. For those interested in the historical perspective of criminal justice, this is a series to note. http://ohiostatepress.org.

Studies in Crime and Public Policy. Oxford: Oxford Univ. Pr., 1996-.

This ongoing series of over forty titles showcases CJAC research that intersects with law and public policy. A strong series to be aware of for criminal justice collections. www. oup.com/us/catalog/general/series/StudiesinCrimeandPublicPolicy.

\section{References and Notes}

1. Otwin Marenin, "Criminology and Criminal Justice: A Comparison," in Encyclopedia of Criminology, ed. Richard A. Wright and J. Mitchell Miller (New York: Routledge, 2005): 331-33.

2. Quint C. Thurman, Lee E. Parker, and Robert L. O'Block, Criminal Justice Research Sources, 4th ed. (Cincinnati, Ohio: Anderson, 2000).

3. Marilyn Lutzker, and Eleanor Ferrall, Criminal Justice Research in Libraries: Strategies and Resources (New York: Greenwood, 1986).

4. Timothy Dodge. "Criminal Justice Web Sites," Reference Services Review 26 (1998): 87-96.

5. Michael S. Vaughn et al., "Journals in Criminal Justice and Criminology," Journal of Criminal Justice Education 15, no. 1 (Spring 2004): 61-192, Academic Search Premier, EBSCOhost (accessed Mar. 13, 2008)

6. Ellen G. Cohn and David P. Farrington, "Scholarly Influence in Criminology and Criminal Justice Journals," Journal of Criminal Justice 36 (2008): 11-21.

\section{WELCOME TO THE TABLE CONTINUED FROM PAGE 12}

For example, I have no idea how many people ask to serve on committees within all of RUSA or what percentage of them get appointed. I don't know how many people attend RUSA programs at ALA Annual Conference or what they think of them. Without hand-counting the constantly changing RUSA committee rosters for the sections and the division, I don't even know how many committee spaces we have to offer our members who want to be appointed.

I do know that RUSA has 5,272 members as of February 2008. 2,427 (approximately 46 percent) of us attended Annual Conference in Washington, D.C., and only 1,516 (approximately 29 percent) of us attended Midwinter Meeting in Philadelphia. Common wisdom has it that you only attend Midwinter Meeting if you are serving on a committee, and, basing my reasoning on that idea, that leaves approximately 71 percent without an active role in RUSA.

The only real way we have right now for RUSA members to share ideas is through the committee structure, and that means the leadership of RUSA hears the voice of less than one-third of its membership. I really am not big on inner circles, small tables, or secret knocks. I think organizations work best when they are welcoming, collaborative, and interested in every voice. The only way to create this type of organization is to listen. To that end, I want to try two new things:

First, I am going to start (and it may end with me) a conference meeting where you are invited to share your ideas. If you plan to attend either Midwinter Meeting in Denver or Annual Conference in Chicago, I invite you to pencil in the first-ever RUSA General Membership meeting. Look for more details on the RUSA website as the conferences draw closer, and come and tell us what you think.

Second, if you do not attend the conferences, or even if you do, I invite you to e-mail me (rusa@ala.org) your thoughts, concerns, suggestions, desires, and grievances. I will not promise to answer you all, but I will promise to listen. My involvement with RUSA has been a constant source of pleasure, growth, and fulfillment. I want to make sure we are doing everything possible so that all of our members can say that as well. 